\title{
A higher dose of enzyme therapy in patients with classic infantile Pompe disease seems to improve ventilator-free survival and motor function
}

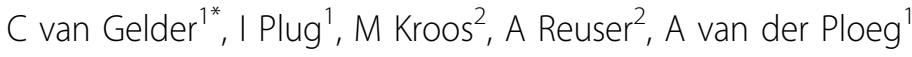 \\ From Proceedings of the 6th European Symposium: Steps Forward in Pompe Disease \\ Berlin, Germany. 23-24 November 2012
}

\begin{abstract}
Introduction
Enzyme replacement therapy (ERT) with Myozyme ${ }^{\circledR}$ has significantly improved the prospect for patients with classic infantile Pompe disease. Yet, about $50 \%$ of patients still do not survive ventilator-free beyond 2.5 years. In the present study we compared the safety and efficacy of treatment with $40 \mathrm{mg} / \mathrm{kg} /$ week to that of $20 \mathrm{mg} / \mathrm{kg} /$ every other week (eow) in 10 infantile patients to determine if a higher/more frequent dose would improve outcomes. All patients were treated for at least one year and received the same dose throughout the study.
\end{abstract}

\section{Results}

Our outcome parameters included survival, ventilator free survival, left ventricular mass index, motor outcome, and infusion associated reactions. A total of six patients received $20 \mathrm{mg} / \mathrm{kg} / \mathrm{eow}$, and four patients received $40 \mathrm{mg} / \mathrm{kg} /$ week. The median treatment duration was 3.5 years and 1.6 years, respectively. The median age at the start of therapy was 1.5 months for the $20 \mathrm{mg} / \mathrm{kg}$ group and 3.1 months for the $40 \mathrm{mg} / \mathrm{kg}$ group. During the treatment period, 3 of the 10 patients became respiratory insufficient. They all belonged to the $20 \mathrm{mg} / \mathrm{kg}$ group, and two of the three were CRIM negative. Four of six patients in the $20 \mathrm{mg} / \mathrm{kg}$ group learned to walk, but two later lost this ability after becoming ventilator dependent. In contrast, all patients from the $40 \mathrm{mg} / \mathrm{kg}$ dose group learned to walk and maintained the ability to walk, even though their baseline motor functioning was generally worse. The decrease in left ventricular mass index and the number of infusion associated reactions was comparable in both groups.

${ }^{1}$ Department of Pediatrics, Center for Lysosomal and Metabolic Diseases, Erasmus MC University Medical Center, Rotterdam, The Netherlands Full list of author information is available at the end of the article

\section{Conclusion}

The preliminary data of our study show that treatment with Myozyme at a higher dose of $40 \mathrm{mg} / \mathrm{kg} /$ week is generally well tolerated and leads to improved ventilator-free survival and motor outcomes than treatment with $20 \mathrm{mg} / \mathrm{kg} /$ eow.

\section{Author details}

'Department of Pediatrics, Center for Lysosomal and Metabolic Diseases, Erasmus MC University Medical Center, Rotterdam, The Netherlands. ${ }^{2}$ Department of Clinical Genetics, Center for Lysosomal and Metabolic Diseases, Erasmus MC University Medical Center, Rotterdam, The Netherlands.

Published: 29 May 2013

doi:10.1186/1471-2474-14-S2-P19

Cite this article as: van Gelder et al:: A higher dose of enzyme therapy in patients with classic infantile Pompe disease seems to improve ventilator-free survival and motor function. BMC Musculoskeletal Disorders 2013 14(Suppl 2):P19.

Submit your next manuscript to BioMed Central and take full advantage of:

- Convenient online submission

- Thorough peer review

- No space constraints or color figure charges

- Immediate publication on acceptance

- Inclusion in PubMed, CAS, Scopus and Google Scholar

- Research which is freely available for redistribution
C Biomed Central

(c) 2013 van Gelder et al; licensee BioMed Central Ltd. This is an Open Access article distributed under the terms of the Creative Commons Attribution License (http://creativecommons.org/licenses/by/2.0), which permits unrestricted use, distribution, and reproduction in any medium, provided the original work is properly cited. 